\title{
Potential and actual trace gas fluxes in Arctic terrestrial ecosystems
}

\author{
Torben Røjle Christensen
}

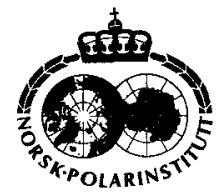

This paper provides an overview of results obtained through a number of studies of actual and potential trace gas exchanges in Eurasian and Greenlandic tundra ecosystems. The chief findings include:

i) Long-term accumulation rates of carbon in organic tundra soils, i.e. net uptake of atmospheric $\mathrm{CO}_{2}$, are strongly controlled by simple climatic parameters (mean July temperature, annual precipitation). Warmer and wetter conditions stimulate carbon sequestration rates in Arctic terrestrial ecosystems.

ii) The release of carbon through ecosystem respiration is also heavily influenced by climate. However, the release of dead organic soil carbon as $\mathrm{CO}_{2}$ is constrained by the lability of the stored organic compounds. This lability decreases significantly with depth (i.e. age) of the soils; moreover, this in turn decreases the temperature sensitivity of the decomposition process.

iii) Methane emissions from typical tundra habitats in northern Eurasia are slightly lower than from seemingly similar habitats in North America although this difference probably can be attributed to the colder climatic setting of the studied sites compared with the general climatic conditions at the North American sites. There is a strong linkage between $\mathrm{CO}_{2}$ exchange, $\mathrm{CH}_{4}$ formation and emission rates in some wet tundra ecosystems.

iv) Atmospheric uptake of $\mathrm{CH}_{4}$ occurs in some dry and mesic tundra habitats and there are indications that these uptake rates could be affected negatively by atmospheric nitrogen deposition. Emissions of $\mathrm{N}_{2} \mathrm{O}$ are rarely seen from Arctic soils but there appear to be a strong potential for denitrification and, hence, $\mathrm{N}_{2} \mathrm{O}$ release. This might be due to high rates of denitrification during the spring thaw and possibly associated significant releases of $\mathrm{N}_{2} \mathrm{O}$ in this period.

T. R. Christensen, Climate Impacts Group, Dept. of Ecology, Plant Ecology, Lund University, Ecology Building, SE-223 62 Lund, Sweden.

\section{Introduction}

Arctic terrestrial ecosystems influence global climate in a number of ways. First, because organic material accumulates in wet tundra ecosystems, these ecosystems have served as sinks for atmospheric $\mathrm{CO}_{2}$ since the last ice age (Adams et al. 1990; Malmer \& Wallen 1996). Second, wet tundra ecosystems constitute a substantial source for atmospheric $\mathrm{CH}_{4}$. The atmospheric input of $\mathrm{CH}_{4}$ from these regions has been estimated to total between 20 and $40 \mathrm{Tg} \mathrm{CH}_{4} / \mathrm{yr}$ (Reeburgh et al. 1994; Christensen, Prentice et al. 1996), which is almost $25 \%$ of the total emissions from natural sources (Fung et al. 1991). In dry and mesic tundra habitats (e.g. Arctic heath ecosystems) there is often an atmospheric uptake of $\mathrm{CH}_{4}$, a process which is closely linked to the nitrogen cycle in the soil.

To improve our understanding of how natural Arctic ecosystems and climate interact it is important to identify and study the controls on these exchanges of trace gases between the Arctic terrestrial ecosystems and climate. Various potential feedback mechanisms on the climate system arising from increased or decreased fluxes of trace 


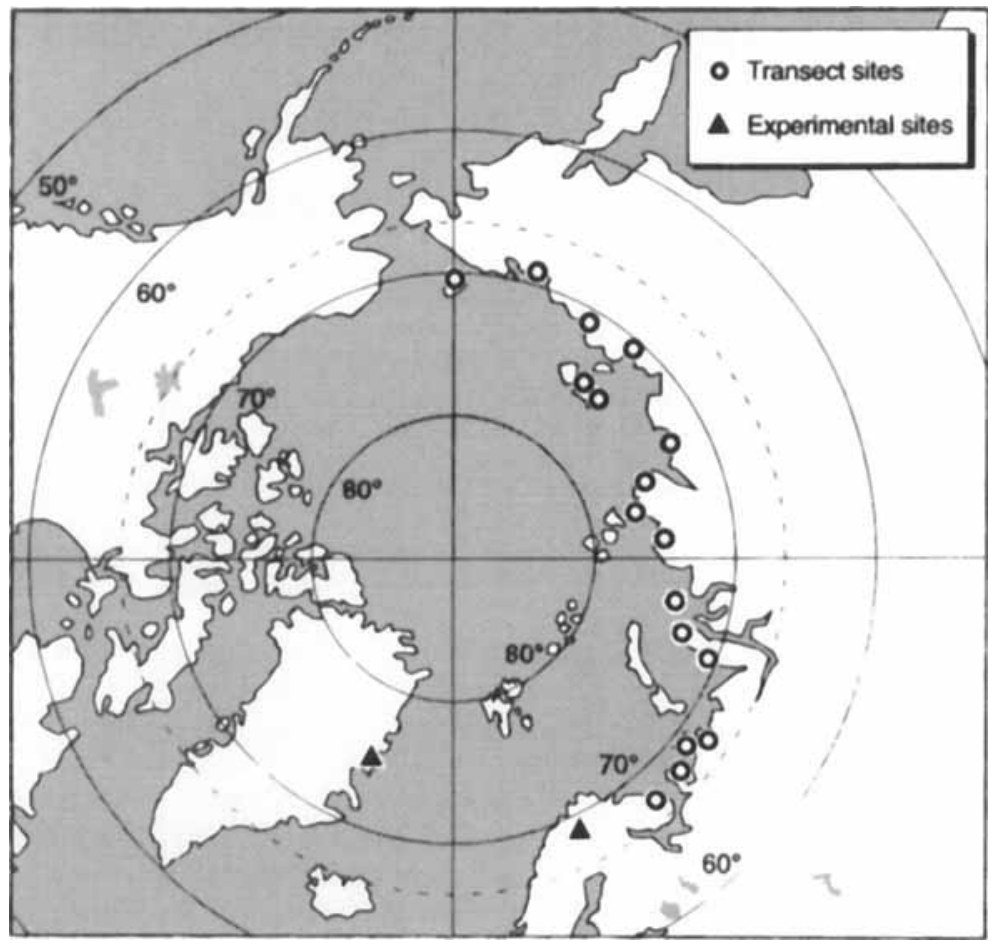

Fig. I. Map showing the locations of the two sets of sites: the Eurasian transect and the experimental sites (from Christensen, Jonasson, Michelsen et al. 1998, $J$. Geophys Res. 103(D22), p. 29016; copyright by the American Geophysical Union; printed with permission of the AGU).

gases following a changing climate in Arctic regions have been suggested (Guthrie 1986; Oechel et al. 1993; Houghton et al. 1995).

Here a brief overview is given of results from studies dealing with the following four issues:

i) long-term carbon accumulation rates in Arctic regions;

ii) controls on ecosystem respiration, i.e. the release of $\mathrm{C}$;

iii) scale of and controls on $\mathrm{CH}_{4}$ emissions;

iv) soil uptake of $\mathrm{CH}_{4}$ and release of $\mathrm{N}_{2} \mathrm{O}$.

The data are from experimental studies at sites ranging from the North Atlantic to the Bering Strait. Emphasis is on Eurasia and Greenland as North America is relatively well-covered in terms of trace gas flux studies.

\section{Study sites}

The results presented are from the following two sets of sites (Fig. 1): a) a transect of sites across northern Eurasia established by the SwedishRussian Tundra Ecology Expedition 1994; b) two permanent experimental sites at sub-Arctic Abisko, northern Sweden and high Arctic Zackenberg, north-eastern Greenland.

\section{Eurasian transect}

Measurements of trace gas fluxes in situ and sampling of soil material were carried out at 17 tundra sites between $67^{\circ}$ and $77^{\circ} \mathrm{N}$ across northern Eurasia as part of the Swedish-Russian Tundra Ecology Expedition 1994 (Christensen, Jonasson, Callaghan \& Havström 1995, 1999; Christensen, Jonasson, Michelsen et al. 1998; Christensen, Jonasson, Callaghan, Havström et al. 1999; Fig. 1). Each site consists of two "subsites," representing mesic and wet tundra habitats. The sites are described in detail in the works just cited. The vegetation of the wet sites was dominated by Carex and Sphagnum spp., whereas the mesic sites were dominated by Eriophorum vaginatum and dwarf shrubs (Christensen, Jonasson, Callaghan \& Havström 1995).

\section{Abisko}

The site studied for responses of trace gas 
Fig. 2. The relative long-term carbon sequestration rates in Eurasian organic tundra soils as a function of mean July temperature along the transect shown in Fig. 1. The magnitude of the slope indicates a progressively slower rate of $\mathrm{C}$ accumulation.

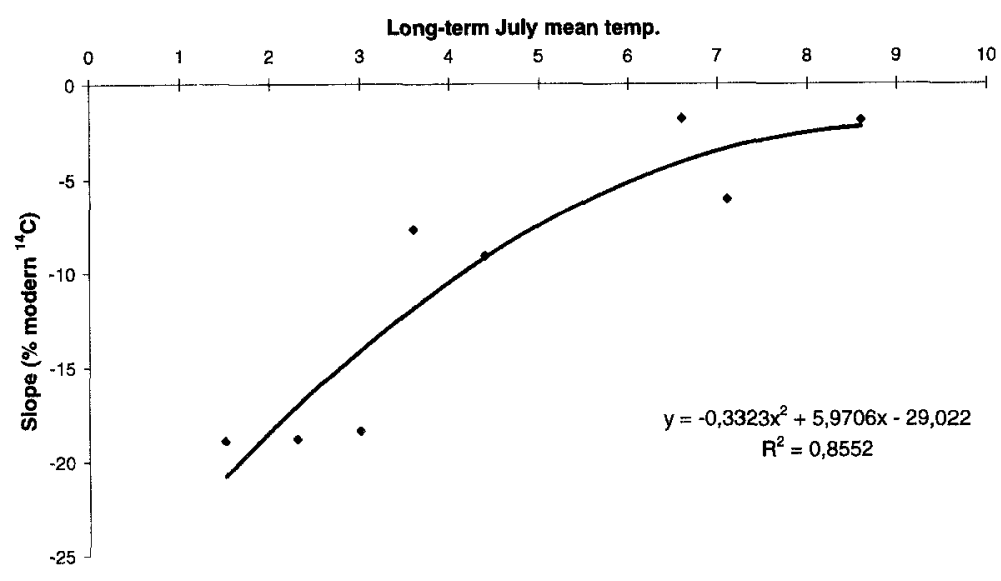

exchange to fertilizer treatments in 1995-96 is at $450 \mathrm{~m}$ asl near Abisko $\left(68^{\circ} 20^{\prime} \mathrm{N}, 20^{\circ} 51^{\prime} \mathrm{E}\right)$ and is dominated by Rhododendron lapponicum, Vaccinium uliginosum, Empetrum hermaphroditum and Betula nana above a subcanopy cover of mosses. The soil has an organic content of $81.4 \pm 1.2 \%$ and a pH of 7.1 (Jonasson et al. 1996).

\section{Zackenberg}

In 1996-97 a drained fen in the high Arctic Zackenberg valley $\left(74^{\circ} 30^{\prime} \mathrm{N}, 21^{\circ} 00^{\circ} \mathrm{W}\right)$ was investigated for the response of respiration to fertilizer applications. The sparse vegetation consisted almost entirely of mosses, among which Drepanocladus revolvens, $D$. brevifolius, Calliergon giganteum, C. richardsonii and Polytrichum swartzii were common. The site has been drained following a thermokarst erosion event and the water table at the experimental site is currently below the freezing horizon all year round.

\section{Methods}

All in situ flux measurements were carried out using standard closed chamber techniques in combination with analyses of $\mathrm{CO}_{2}, \mathrm{CH}_{4}$ and $\mathrm{N}_{2} \mathrm{O}$ by either infra-red gas analyses $\left(\mathrm{CO}_{2}\right)$ or gas chromatography $\left(\mathrm{CO}_{2}, \mathrm{CH}_{4}\right.$ and $\left.\mathrm{N}_{2} \mathrm{O}\right)$. The techniques are described in detail in Christensen, Jonasson, Callaghan \& Havström (1995, 1999), Christensen, Jonasson, Michelsen et al. (1998), and Christensen, Michelsen \& Jonasson (1999).

From the Eurasian transect soil samples were brought back to laboratories in Copenhagen and Lund. The soils were divided into different depth increments depending on the degree of humification and cleared for any visible remains of vascular plant roots. These samples were used for decay potential incubations (Christensen, Jonasson, Callaghan \& Havström 1999) and ${ }^{14} \mathrm{C}$ analyses using AMS (Christensen, Jonasson, Callaghan, Havström et al. 1999).

\section{Results and discussion}

\section{i) Long-term carbon accumulation rates}

Figure 2 shows preliminary results from an analysis of ${ }^{14} \mathrm{C}$ with depth in cores taken back from the Eurasian transect of sites (Christensen, Jonasson, Callaghan, Havström et al. 1999). A high "\% ${ }^{14} \mathrm{C}$ modern" slope indicates a relatively slow carbon sequestration rate, i.e. that one quite rapidly reaches older material when moving down the soil profile. From this simple plot of the relative sequestration rates against a key climatic parameter - mean July temperature - a clear correlation appears. Similarly, there is also a positive correlation between the ${ }^{14} \mathrm{C}$ slope and annual precipitation. Hence, warmer and wetter conditions seem to stimulate the carbon sequestration in the Arctic.

Peat accumulation is a predominantly northern phenomenon (Clymo 1983). Relative cold and wet conditions generally cause greater constraints on heterotrophic respiration rates than on photosynthesis. The pattern we have found in the Arctic, 
in which warmer temperatures seem to increase carbon sequestration rates, therefore indicates that we are here situated north of the zone with the most optimal conditions for carbon accumulation and peat formation. It also indicates that the Arctic might have a potential for further sequestration of carbon in a possible warmer and wetter climate. In a drier climate the opposite could be the case.

\section{ii) Controls on $\mathrm{CO}_{2}$ release from Arctic ecosystems}

Figure 3 shows the correlation between ecosystem (soil plus plant) respiration rates and simple climatic parameters as observed along the transect of wet tundra habitats across northern Eurasia. A clear climatic control can be seen. Respiration increases with increasing temperatures, and a deeper water table causes the more efficient aerobic decomposition to dominate over the anaerobic processes which also leads to an increased release of $\mathrm{CO}_{2}$ (Christensen, Jonasson, Michelsen et al. 1998).

Figure 4 shows an estimated quantification of the proportional contribution to the surface $\mathrm{CO}_{2}$ efflux of different depth layers in wet and mesic tundra soils. The estimation is based on a progressive decrease in the explained variance of surface fluxes by soil temperatures with depth reported in Christensen, Jonasson, Michelsen et al. (1998) and the declining potential $\mathrm{CO}_{2}$ production with depth documented in Christensen, Jonasson, Callaghan \& Havström (1999). In wet tundra systems more than $90 \%$ of the $\mathrm{CO}_{2}$ measured in the surface flux measurements is estimated to originate in the top $5 \mathrm{~cm}$ of the soil and over $70 \%$ from the top $2 \mathrm{~cm}$. Due to the more aerated soil conditions, mesic tundra soils are estimated to have a less steep decline in the relative contribution with depth, with $90 \%$ of the $\mathrm{CO}_{2}$ seen in the surface flux originating from the top $10 \mathrm{~cm}$. This crude estimation illustrates that the widely used dark chamber $\mathrm{CO}_{2}$ flux measuring technique predominantly documents the turnover of very recently fixed organic material. It may, therefore, be less suited for investigations of longer term $\mathrm{C}$ dynamics and potential releases as $\mathrm{CO}_{2}$ of the less labile carbon stored at depth in the soil layers and peat proper.

As the quantitatively most important decomposition takes place in the topmost layer of the soil
(Fig. 4) little of the variance in $\mathrm{CO}_{2}$ flux, as measured in situ, was explained by the thaw depth (Fig. 3) and no correlation was found with the organic matter content in the soil (Christensen, Jonasson, Callaghan \& Havström 1995; Christensen, Jonasson, Michelsen et al. 1998). However, one could have expected a correlation between thaw depth, soil temperature and water content: a shallow active layer should result in low soil temperatures and a high degree of water logging. The lack of correlation, at least at the wet sites, was due to the soils having a water table above, or very close to, the soil surface so that the water table and the top soil temperatures had the overriding effect. Second, as mentioned above, the decay potential decreases strongly with soil depth (Christensen, Jonasson, Callaghan \& Havström 1999). Hence, the water and temperature conditions in the upper few centimetres have much stronger influence on the $\mathrm{CO}_{2}$ evolution per unit area than the conditions in the deeper layers, which are mostly affected by the position of the permafrost table.

The potential $\mathrm{CO}_{2}$ evolution rates did not show any correlation with the $\mathrm{N}$ content of the soils (Christensen, Jonasson, Callaghan \& Havström 1999) and neither did it correlate in the in situ measurements (Fig. 3). Total $\mathrm{N}$ concentration is a crude measure and it is difficult to interpret the present result in relation to possible direct effects of the soil nutritional status on decomposition rates. Earlier studies have shown that decomposition generally increases with reduced $\mathrm{C} / \mathrm{N}$-ratio. We assume that the lack of correlation in our study is because the material analysed for $\mathrm{N}$ was from peaty soils with very high $\mathrm{C} / \mathrm{N}$-ratios of $40-50$ in the top soil (Christensen, Jonasson, Callaghan \& Havström 1999) and that decomposition processes are affected only at significantly lower values. However, an experimental study of soil respiration rates in response to factorial NPK fertilizer experiments showed that at both a sub-Arctic and high Arctic habitat adding $N$ to the soils had very little effect on respiration rates (Christensen, Jonasson, Michelsen et al. 1998). Adding a labile carbon source to the high Arctic organic soil, in contrast, caused strong immediate increase in $\mathrm{C}$ mineralization rates (Illeris et al. in prep.).

Combined with the information above, the decline in relative $\mathrm{CO}_{2}$ production rates with depth (Fig. 4) indicates that under constant temperature and moisture conditions the $\mathrm{CO}_{2}$ production rate is largely limited by the proportion 


\section{Wet tundra}

(a)

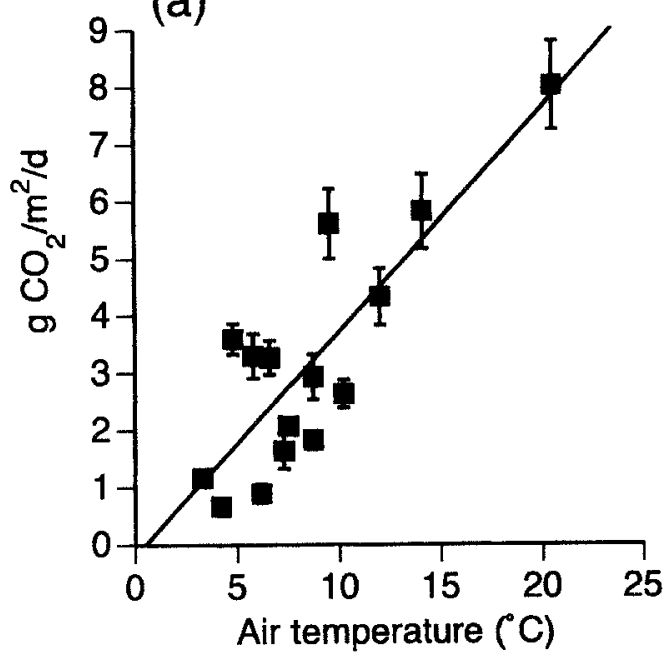

(c)

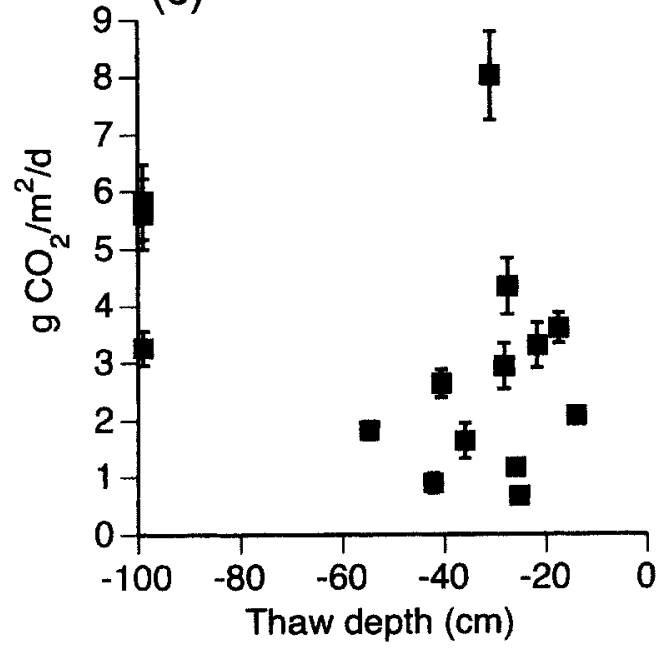

(b)

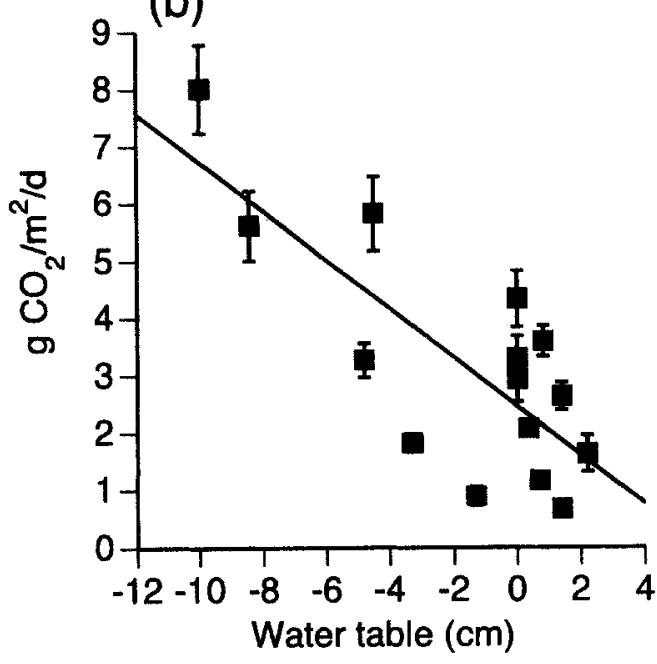

(d)

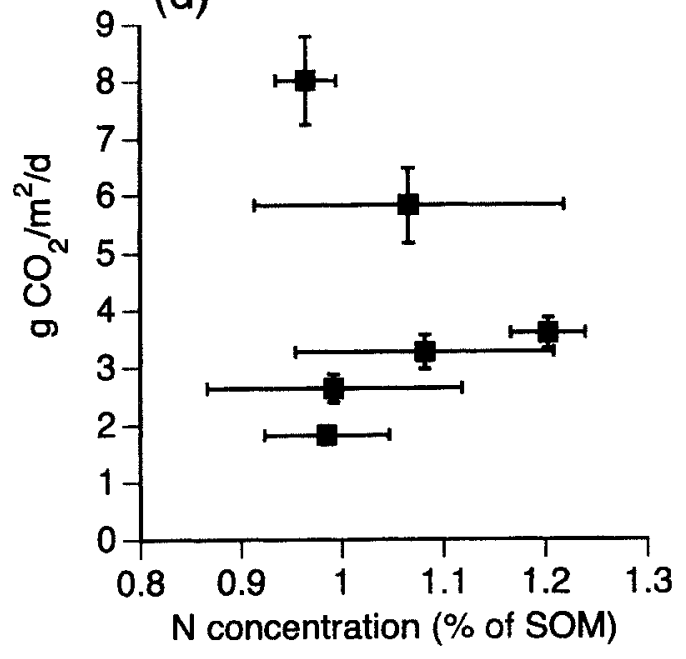

Fig. 3. Correlations between environmental parameters and wet tundra ecosystem respiration rates as observed in field daytime chamber measurements ( $\mathrm{n}=10$ ) along the Eurasian transect during the summer of 1994 . Lines are only drawn for linear regressions showing statistically significant relationships (adapted from Christensen, Jonasson, Michelsen et al. 1998, J. Geophys Res. $103(\mathrm{D} 22)$, p. 29017; copyright by the American Geophysical Union; printed with permission of the AGU).

of recalcitrant carbon, which increases with the age of the organic matter, while the relative $\mathrm{N}$ content, which usually shows a positive correlation with the decomposability of young organic matter (e.g. Heal et al. 1982) has less effect. This is in accordance with established data on factors affecting decay rates in peat accumulating systems (Heal et al. 1982; Clymo 1983).

iii) Scale of and controls on $\mathrm{CH}_{4}$ emissions

The general scale of methane emissions found 


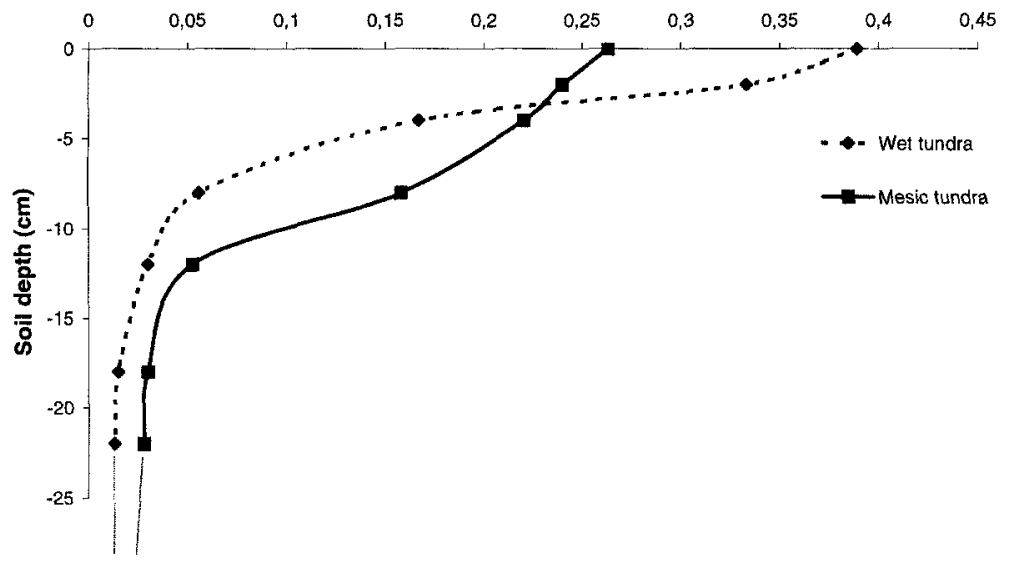

Fig. 4. Estimated relative proportions of $\mathrm{CO}_{2}$ produced at different soil depths contributing to the surface efflux of $\mathrm{CO}_{2}$ as measured by conventional dark chamber techniques. The estimation is based on a statistical analysis of the variance in surface fluxes explained by soil temperatures at depth and a study of potential $\mathrm{CO}_{2}$ evolution from soil material at different depth layers.

along the transect across northern Eurasia was somewhat lower than that found in North American studies. The daytime flux in wet tundra habitats was found to average $47 \mathrm{mg} \mathrm{CH}_{4} / \mathrm{m}^{2} /$ day, which is about half a similar average for a large number of studies predominantly in North America (Christensen, Jonasson, Callaghan \& Havström 1995; Christensen, Jonasson, Callaghan, Havström et al. 1999). However, the study in Siberia is from considerably colder habitats than most studies in Arctic North America and in this respect the emissions found in Siberia were quite high. It might also be noted that recent studies in high Arctic Greenland have found emission rates very similar to those found during the transect across Siberia (Christensen, Friborg et al. in press; Friborg et al. in press).

Soil climate imposes an important control on the release rates of $\mathrm{CH}_{4}$ from tundra habitats. Warmer and wetter soil conditions generally cause higher emissions (Christensen, Jonasson, Callaghan \& Havström 1995). However, simple indicators such as soil temperature and water table have failed to predict the differences found in the general scale of emissions between sites and studies (e.g. Roulet et al. 1994). The net ecosystem exchange of carbon has been suggested as having an important control on $\mathrm{CH}_{4}$ emissions (e.g. Whiting \& Chanton 1993; Joabsson et al. 1999a). This control may be caused by the vascular plants actively transporting $\mathrm{CH}_{4}$ from the anaerobic zone, where it is produced, to the atmosphere. It may also be caused by the vascular plant roots providing a labile substrate for the methanogenic bacteria at depth in the soil. The influence varies with the species composition of the vascular plants and in many instances it might be a combination of the mentioned factors (Waddington et al. 1996; Joabsson et al. 1999a). For example, we have found an intimate connection between net $\mathrm{CO}_{2}$ flux and $\mathrm{CH}_{4}$ emission in a high Arctic fen area (Christensen, Friborg et al. in press) while Joabsson et al. (1999b) reports on a considerable temporal delay in the coupling between $\mathrm{CO}_{2}$ and $\mathrm{CH}_{4}$ fluxes in an experiment on peat monoliths from a boreal bog.

\section{iv) $\mathrm{CH}_{4}$ uptake and $\mathrm{N}_{2} \mathrm{O}$ emissions}

In an experimental study of the sub-Arctic heath site near Abisko (Christensen, Michelsen \& Jonasson 1999) we showed that $\mathrm{CH}_{4}$ oxidation was strongly inhibited by inorganic and organic $\mathrm{N}$ additions and that there were indications this inhibition was associated with limited rates of nitrification. Contrary to the findings of Kruse \& Iversen (1995) in a temperate heath soil and to our own findings in a different but nearby habitat (Christensen, Michelsen, Jonasson et al. 1997), it seems that increased $\mathrm{N}$ deposition rates in this habitat would decrease atmospheric $\mathrm{CH}_{4}$ consumption rates, as also suggested in other studies (e.g. Steudler et al. 1989; Schnell \& King 1994). Inorganic $\mathrm{N}$ additions greatly increased $\mathrm{N}_{2} \mathrm{O}$ emission rates, while organic additions that approximately doubled soil $\mathrm{NH}_{4}$ concentrations had little effect on the $\mathrm{N}_{2} \mathrm{O}$ flux. This indicates that $\mathrm{N}_{2} \mathrm{O}$ was produced as a result of denitrification and not by nitrification, and that slow nitrification rates relative to the potential for denitrification are characteristic features of this sub-Arctic heath site, 


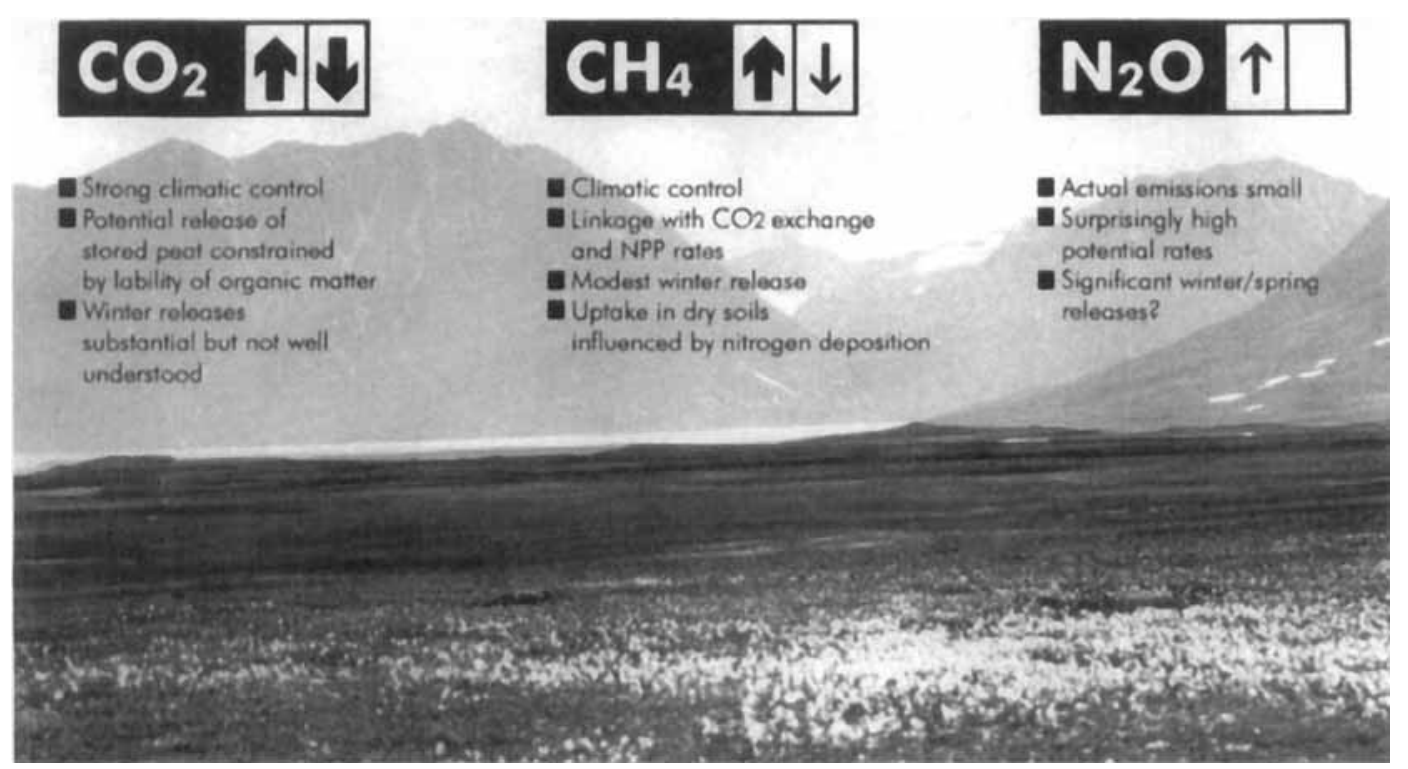

Fig. 5. Summary of the scales of and controls on actual and potential $\mathrm{CO}_{2}, \mathrm{CH}_{4}$ and $\mathrm{N}_{2} \mathrm{O}$ fluxes in tundra environments. The thickness of the arrows indicate the strength of the potential to act either as an atmospheric sink or source (or both) for the trace gases in question. Zackenberg Valley, north-eastern Greenland, in the background.

as has been shown for temperate peat soils (Aerts 1997).

The great potential for denitrification is somewhat surprising as normally very little nitrate is found in these soils. This may be a result of most studies having concentrated on sampling during the summer. Denitrification has been found to take place even below the freezing point (Malhi et al. 1990; Dorland \& Beauchamp 1991). During freezing and thawing carbon is liberated, which may increase the denitrification activity in the soil (Christensen \& Christensen 1991). During the spring thaw of the soil, a significant proportion of the annual emission of $\mathrm{N}_{2} \mathrm{O}$ may take place. The $\mathrm{N}_{2} \mathrm{O}$ emitted during the thawing could, however, also have been produced during the frozen period - trapped by the ice, and then liberated during the thawing. The potential releases of $\mathrm{N}_{2} \mathrm{O}$ (and other trace gases) during winter and spring thaw periods is an issue which needs further attention.

\section{Summary}

Figure 5 summarizes the findings presented in this paper. There are strong climatic controls on $\mathrm{CO}_{2}$ exchanges in tundra ecosystems providing the potential for substantial feedback mechanisms in connection with possible changes in climate. The potential releases of stored peat as $\mathrm{CO}_{2}$ to the atmosphere are constrained, however, by the lability of the organic material. There are substantial releases of $\mathrm{CO}_{2}$ during winter but the dynamics of this are not well understood. As for $\mathrm{CO}_{2}$, there are also strong climatic controls on $\mathrm{CH}_{4}$ exchange in tundra ecosystems. This atmosphere/ ecosystem exchange of $\mathrm{CH}_{4}$ is also strongly influenced by vascular plant productivity. Atmospheric uptake of $\mathrm{CH}_{4}$ occurs in dry tundra ecosystems, a process which could be affected by nitrogen deposition. A significant potential for $\mathrm{N}_{2} \mathrm{O}$ release from tundra soils has been shown, indicating possible high rates of denitrification during the spring thaw period.

Acknowledgements. - This brief overview is based on a series of original contributions carried out in conjunction with $S$. Jonasson, A. Michelsen, T. V. Callaghan, M. Havström, F. Livens, N. Panikov and L. Klemmedtson. The work was supported financially by the EC Environment and Climate Programme, the Danish Research Council's Polar Programme, the Swedish Environmental Protection Agency and the Swedish Polar Research Secretariat. 


\section{References}

Adams, J. M., Faure, H., Faure-Denard, L., Mcglade, J. M. \& Woodward, F. L. 1990: Increases in terrestrial carbon storage from the Last Glacial Maximum to the present. Nature 348 , 711-714.

Aerts, R. 1997: Atmospheric nitrogen deposition affects potential denitrification and $\mathrm{N}_{2} \mathrm{O}$ emission from peat soils in The Netherlands. Soil Biol. Biochem. 29, 1153-1156.

Christensen, S. \& Christensen, B. T. 1991: Organic matter available for denitrification in different soil fractions: effect of freeze/thaw cycles and straw disposal. J. Soil Sci. 42, 637-647.

Christensen, T. R., Friborg, T., Sommerkorn, M., Kaplan, J., Illeris, L., Soegaard, H., Nordstroem, C. \& Jonasson, S. in press: Trace gas exchange in a high Arctic valley 1: variations in $\mathrm{CO}_{2}$ and $\mathrm{CH}_{4}$ flux between tundra vegetation types. Global Biogeochem. Cycles.

Christensen, T. R., Jonasson, S., Callaghan, T. V. \& Havström, M. 1995: Spatial variation in high latitude methane flux along a transect across Siberian and European tundra environments. J. Geophys. Res. I00D, 21035-21045.

Christensen, T. R., Jonasson, S., Callaghan, T. V. \& Havström, M. 1999: On the potential $\mathrm{CO}_{2}$ releases from tundra environments in a changing climate. Appl. Soil Ecol. 11 , 127-134.

Christensen, T. R., Jonasson, S., Callaghan, T. V., Havström, M. \& Livens, F. R, 1999: Carbon cycling and methane exchange in Eurasian tundra ecosystems. Ambio 28, 239-244.

Christensen T. R., Jonasson S., Michelsen A., Callaghan, T. V. \& Havström, M. 1998: Environmental controls on soil respiration in the Eurasian and Greenlandic Arctic. $J$. Geophys. Res. 103(D22), 29015-29021.

Christensen, T. R., Michelsen, A. \& Jonasson, S. 1999: Exchange of $\mathrm{CH}_{4}$ and $\mathrm{N}_{2} \mathrm{O}$ in a subarctic heath soil: effects of inorganic $\mathrm{N}$ and $\mathrm{P}$ amino acid addition. Soil Biol. Biochem. $31,637-641$.

Christensen, T. R., Michelsen, A., Jonasson, S. and Schmidt, I. K. 1997: Carbon dioxide and methane exchange of a subarctic heath in response to climate change related environmental manipulations. Oikos 79, 34-44.

Christensen, T. R., Prentice, I. C., Kaplan, J., Haxeltine, A. \& Sitch, S. 1996: Methane flux from northern wetlands and tundra: an ecosystem source modelling approach. Tellus $48 B$, 651-660.

Clymo, R. S. 1983: Peat. In A. J. P. Gore (ed.): Ecosystems of the world 4A, mires: swamp, bog, fen and moor. Pp. 159-224. Oxford: General Studies Elsevier.

Dorland, S. \& Beachamp, E. G. 1991: Denitrification and ammonification at low soil temperatures. Can. J. Soil Sci. 42 , $162-171$.

Friborg, T., Christensen, T. R., Hansen, B. U., Nordstroem, C. \& Soegaard. $H$. in press: Trace gas exchange in a high Arctic valley 2: landscape $\mathrm{CH}_{4}$ fluxes measured and modelled using eddy correlation data. Global Biogeochem. Cycles.

Fung, I., John, J., Lerner, J., Matthews, E., Prather, M., Steele, L. P. \& Fraser, P. J. 1991: Three-dimensional model synthesis of the global methane cycle. J. Geophys. Res. $96 D$, 13033-13065.

Guthrie, P. D. 1986: Biological methanogenesis and the $\mathrm{CO}_{2}$ greenhouse effect. $J$. Geophys. Res. $91($ D10), 10,847-10,851.
Heal, O. W., Flanagan, P. W., French, D. D. \& Maclean, S. F. 1982: Decomposition and accumulation of organic matter. In L. C. Bliss et al. (eds.): Tundra ecosystems: a comparative analysis. Pp. 587-633. Cambridge: Cambridge University Press.

Houghton, J. T., Meira Filho, L. G., Bruce, J., Hoesung, L., Callander, B. A., Haites, E., Harris, N. \& Maskell, K. (eds.) 1995: Climate change 1994, radiative forcing of climate change and an evaluation of the IPCC IS92 Emission Scenarios. Cambridge: Cambridge University Press.

Joabsson, A., Christensen, T. R. \& Wallén, B.1999a: Vascular plant controls on methane emissions from northern peatforming wetlands. Trends Ecol. Evol. 14, 385-388.

Joabsson, A., Christensen, T. R. \& Wallén, B. 1999b: Influence of vascular plant photosynthetic rate on $\mathrm{CH}_{4}$ emission from peat monoliths from southern boreal Sweden. Polar Res. I8(2), 215-220.

Jonasson, S., Michelsen, A., Schmidt, I. K., Nielsen, E. V. \& Callaghan, T.V. 1996: Microbial biomass C, N and P in two Arctic soils and responses to addition of NPK fertilizer and sugar: implications for plant nutrient uptake. Oecologia 106, 507-515.

Kruse, C. W. \& Iversen, N. 1995: Effect of plant succession, ploughing and fertilization on the microbiological oxidation of atmospheric methane in a heathland soil. FEMS Microbiol. Ecol. 18, 121-128.

Malhi, S. S., McGill, W. B. \& Nyborg, M. 1990: Nitrate losses in soils: effect of temperature, moisture and substrate concentration. Soil Biol. Biochem. 22, 733-737.

Malmer, N. \& Wallén, B. 1996: Peat formation and mass balance in subarctic ombrotrophic peatlands around Abisko, northern Scandinavia. In P. S. Karlsson \& T. V. Callaghan (eds.): Plant ecology of the subarctic Swedish Lapland. Ecol. Bull. (Copenhagen) 45, 79-92.

Oechel, W. C., Hastings, S. T., Vourlitis, G., Jenkins, M., Riechers, G. \& Grulke, N. 1993: Recent change of Arctic tundra ecosystems from a net carbon dioxide sink to a source. Nature 361, 520-523.

Reeburgh, W. S.. Roulet, N. T. \& Svensson, B. 1994: Terrestrial biosphere-atmosphere exchange in high latitudes. In $\mathrm{R} . \mathrm{G}$. Prinn (ed.): Global atmospheric-biospheric chemistry. Pp. 165-178. New York: Plenum Press.

Roulet, N. T., Jano, A., Kelly, C. A., Klinger, L., Moore, T. R., Protz, R., Ritter, J. A. \& Rouse, W. R. 1994: Role of the Hudson Bay lowland as a source of atmospheric methane. $J$. Geophys. Res. 99D, 1439-1454.

Schnell, S. \& King, G. M. 1994: Mechanistic analysis of ammonium inhibition of atmospheric methane consumption in forest soils. Appl. Env. Microbiol. 60, 3514-3521.

Steudler P. A., Bowden R. D., Mellillo, J. M. \& Aber, J. D. 1989: Influence of nitrogen fertilization on methane uptake in temperate forest soils. Nature 341, 314-316.

Waddington, J. M., Roulet, N. T. \& Swanson, R. V. 1996: Water table control of $\mathrm{CH}_{4}$ emission enhancement by vascular plants in boreal peatlands. J. Geophys. Res. 101 , 22775-22785.

Whiting, G. J. \& Chanton, J. P. 1993: Primary production control of methane emission from wetlands. Nature 364 , 794-795. 